\title{
Hertuger, amtmænd og befalingsmænd i Løgumkloster $1544-1616$
}

\section{En nøgle til Løgumkloster slot}

\section{af Niels T. Sterum}

Det er hidtil antaget, at slottet i Løgumkloster er opført i 1614. Der findes imidlertid ikke kilder, som bekræfter denne datering. På baggrund af både skriftlige kilder og nyere arkæologiske undersøgelser belyser mag.art. Niels Sterum her nybyggerierne $i$ Løgumkloster i tiden efter klostrets ophævelse. Der argumenteres for, at slottet kan være opført i årene 1581-86.

Sædvanligvis betragtes det lille Løgumkloster amt som et appendiks til andre sønderjyske amter, og det er da også rigtigt, at fra 1598 til amtets ophævelse i 1867 blev Løgumkloster amt styret sammen med andre amter (Tønder, Aabenraa, Svavsted) - bortset fra nogle korte perioder, hvor amtet var under direkte gottorpsk forvaltning. Det er også rigtigt, at den til enhver tid fungerende amtmand efter 1598 havde sin residens et andet sted end Løgumkloster. Men hvorledes var det før 1598 ? Her er kilderne øjensynligt usikre og uklare, hvorfor spørgsmålet om amtets selvstændighed oftest forbigås i stilhed.'

Når spørgsmålet her tages op til overvejelse, skyldes det, at amtets forhold er et vigtigt led $i$ rekonstruktionen af baggrunden for opførelsen af en af de få renlivede renæssancebygninger, som er bevaret i Nordslesvig: slottet $\mathrm{i}$ Løgumkloster. Med denne betegnelse menes næsten altid kun den $44 \mathrm{~m}$ lange og to stokværk høje bygning, som støder op til sydvesthjørnet af cisterciensernes vidt berømte klosterkirke.

Ad arkæologisk vej ${ }^{2}$ er det imidlertid lykkedes at vise, at slottet var et vidtløftigt voldgravomkranset anlæg med bl.a. en central slotsfirkant, der skabtes ved udbygning mod vest af den gamle middelalderlige klosterfirkant. Tilbygningen ved kirken var nordfløj $\mathrm{i}$ udbygningen og er den eneste bevarede renæssancedel af slottet. Fløjen var slottets hovedfløj, som i andet stokværk rummede en typisk 1500-tals fyrstebolig med en stor sal i midten og ved hver ende heraf to rum i forlængelse af hinanden beregnet som et fyrstepars private gemakker. 


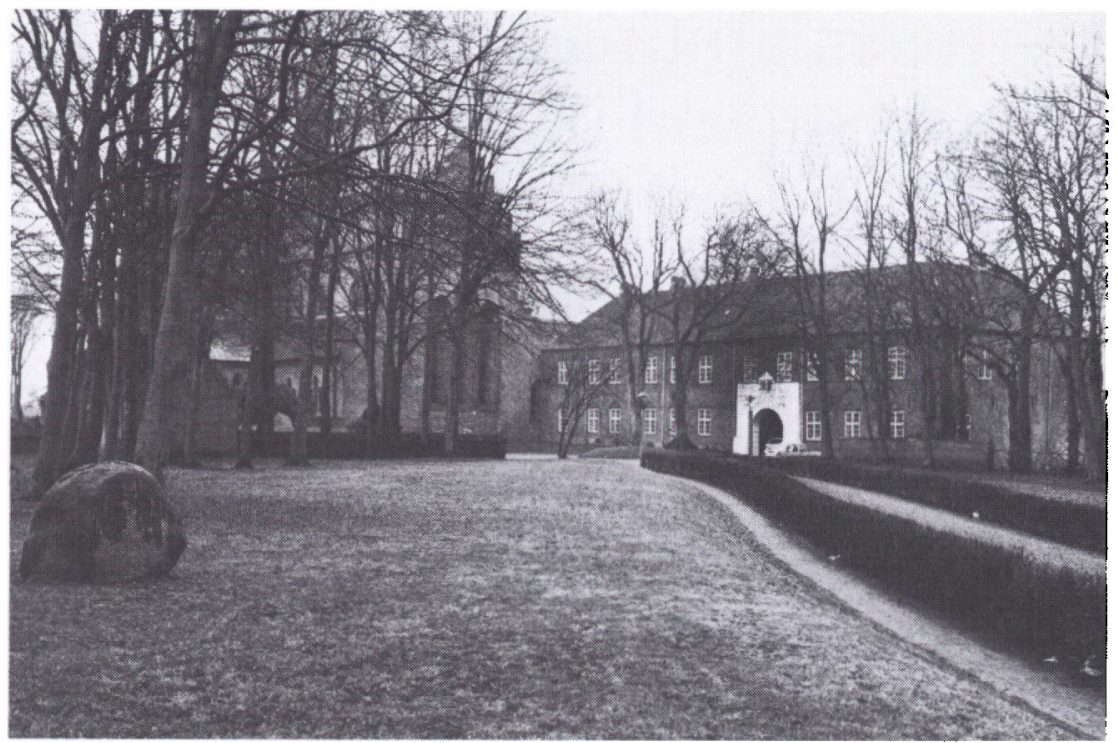

Slottet i Logumkloster opstod ved en udbygning af klostret, hvorved den gamle kirke fik en ny funktion som slotskirke. Den nyopforte hovedfloj virker lidt uanseelig ved siden af kirken, men faktisk er de to bygninger af samme longde. Flojens oprindelige karakter er svakket af et afvalmet tag fra nyere tid; tidligere havde bygningen sadeltag med stengavle $i$ ost og vest samt en mindre, muret gavl $i$ nord, velsagtens over portalen. Set fra nordvest. NTS fot. 1986.

\section{»Indskriften« der blev borte}

Bygningen er stædigt blevet dateret til 1614, først med en henkastet bemærkning om at den "ser ud til at vare bygget $1614 \ll,{ }^{3}$ senere med en påstand om at den mefter en halvt udslidt indskrift er ... opført $1614 \ldots$... $^{4}$ Bygherren skulle efter det ofte gentagne bygningsår være hertug Johann Adolf af Gottorp.

Lad os et øjeblik beskæftige os med denne whalvt udslidte indskrift«. Den toner svagt frem første gang i 1929 under omtalen af de våbentavler, som dengang var at se over porten på bygningens nordfacade. Herom hed det, at den oprindelige bygherres våben (altså Johann Adolfs våben) var "1721 blevet borthugget og erstattet med det danske rigsvåben og Fr. IV's kronede navnetræk; endnu kan den oprindelige indskrift dog skimtes «. ${ }^{5}$ Ingen nærmere dokumentation om det, der skimtes!

Ganske få år efter blev bygningen restaureret. Herunder blev våbentavlerne nedtaget, og på bagsiden af tavlerne fandt man det, som man troede borthugget fra forsiden: våbentavlerne for hertug Johann Adolf og gemalinden Augu- 
sta! Der var altså ikke foregået en borthugning, tavlerne var blot blevet vendt for at give plads til Frederik IV's våben!

Denne nye iagttagelse blev omhyggeligt publiceret i $1932^{4}$ af den samme forfatter, som i 1929 havde kunnet skimte en indskrift. Der redegøres omhyggeligt for de nyfundne våbenskjolde, også for indskriften på Augustas våbenskjold (hertugindens valgsprog), og intet havde været mere naturligt end også at redegøre for den indskrift, som forfatteren kunne skimte ganske få år forinden. Men den lærde forfatter, som var ingen ringere end Nationalmuseets daværende direktør, gled let hen over den sag og skrev nu blot i en sammenhæng, som er helt løsrevet fra våbentavlerne, at bygningen wefter en halvt udslidt indskrift er ... opført 1614 af den gottorpske hertug Johan Adolf « ${ }^{4}$ Ingen nærmere dokumentation!

Nøgternt vurderet må man i dag konkludere, at en indskrift med angivelse af årstallet 1614 næppe nogensinde har været at se - og da slet ikke i forbindelse med Frederik IV's tavler. Den formodede borthugning af oprindelige tavler var forudsætningen for, at en oprindelig indskrift overhovedet kom på tale. $\mathrm{Da}$ denne forudsætning faldt bort, faldt også hele ideen om en oprindelig indskrift bort. Herefter må bygningsåret 1614 for stedse være manet $\mathrm{i}$ jorden!

Men når nu hertug Johann Adolfs våben faktisk fandtes på bygningen, var han så alligevel bygherren? Hertil må man sige: ikke nødvendigvis. Hans våben kan let forklares blot som en markering af, at han ejede Løgumkloster slot (i perioden 1590-1616). Det ses hyppigt, at bygningstavler ikke angiver bygherren, men en senere ejer. Eksempelvis anbragte Johann Adolf sit våbenskjold over indgangen til hovedbygningen af det Husum slot, som hans far, hertug Adolf, havde bygget.

Om Johann Adolf vides $\mathrm{i}$ øvigt, at han var meget optaget af at forbedre og forskønne interiørerne på slottene i Husum og Gottorp og meget lidt optaget af nybyggerier. Alene af den grund forekommer han ikke meget sandsynlig som bygherre for et stort anlagt slot i Løgumkloster.

\section{Fra klostergods til selvstændigt amt}

Men hvem var da bygherren i Løgumkloster? Indtil nu er der ikke fremdraget skriftlige kilder med oplysning herom, og foreløbig har arkæologiske fund ikke givet mere præcis datering end til 1500-tallets anden halvdel eller 1600tallets første del - den samme brede datering som stilhistorisk kan aflæses af den meget enkle arkitektur. Når disse kilder svigter, er man henvist til at gisne - og da bedst ud fra det bredest mulige kildemateriale til belysning af udviklingen i Løgumkloster fra 1500-tallets midte til et stykke ind i 1600- 


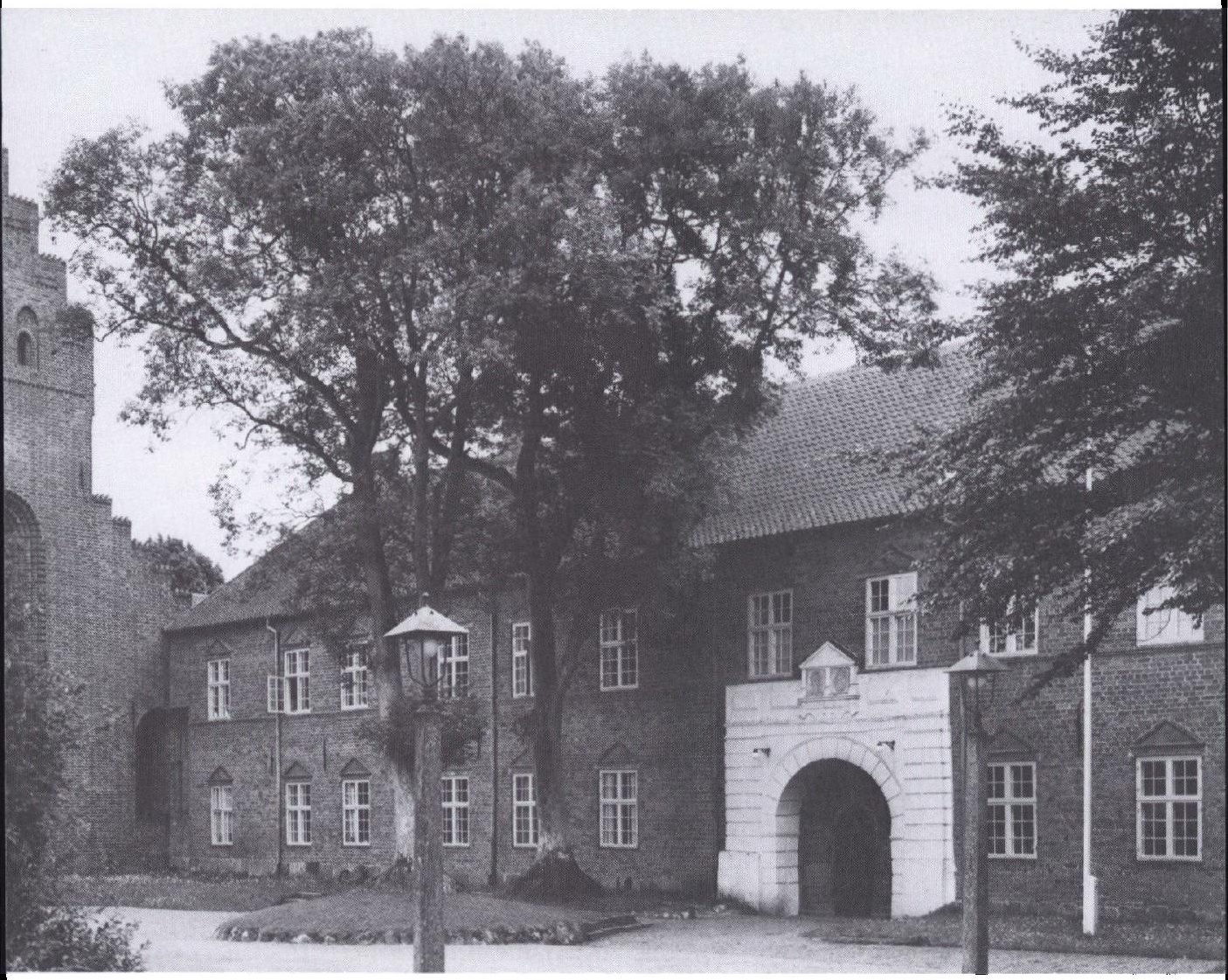

Den monumentale indramning af porten i hovedflejens nordfacade synes anbragt en tid efter bygningens fardiggerelse. Bygningstavlerne over porten er helt sikkert uden oprindelig sammenhang med portindfatningen. Tavlerne pd bygningen er kopier, originalerne findes pd Tonder Museum. Lennart Larsen fot. 1963.

tallet. Her får det betydning at samle de tilgængelige oplysninger om Løgumkloster $a m t^{6}$ og derefter søge at vurdere, hvornår der forelå en optimal situation, hvori slottet mest sandsynligt kunne være bygget.

Det er uklart, hvornår og hvorledes Løgumkloster amt blev etableret som et forvaltningsområde på basis af klostergodset, der havde tilhørt cisterciensermunkene i Løgum. Ofte anføres 1548 som amtets oprettelsesår, ${ }^{7}$ hvilket er klart forkert, sådan som det vil fremgå af det folgende.

Tilsyneladende blev den gejstlige klosteradministration langsomt og glidende afløst af en verdslig administration i årene efter 1542, hvor reformationen officielt blev gennemført i Sønderjylland. Men allerede længe før 1542 havde 
hertug Frederik I af Gottorp udøvet en vis magt over klostret. I 1491 erhvervede hertugen nogle jagt- og gasterettigheder i klostret, og i 1500-tallet tvangsudskrev hertugen ved flere lejligheder både arbejdskraft, pligtkørsler og materialeleverancer fra klostret. Således måtte klostrets bønder i 1511 fremskaffe og transportere træ og tørv til hertugens digebyggeri ved Tønder, ${ }^{8}$ og i 1522 blev bønderne indkaldt til befæstningsarbejde ved Tønder slot. ${ }^{9}$ Måske havde de "klosterfogeder", som nævnes $1494^{10}$ og 1502, " en relation til hertugen (udnævnt af hertugen?).

Umiddelbart efter 1542 må den gejstlige ledelse af klostret tænkes fortsat uforandret, og at klostret tilfaldt hertug Hans den Fldre af Haderslev ved Sønderjyllands deling i 1544 medførte ifølge den hidtidige forskning heller ingen øjeblikkelig forandring. Man har lagt vægt på, at klosterkonventet på tilsyneladende normal vis i 1546 valgte en ny abbed, Morten Iversen. ${ }^{12}$ Denne abbed døde i $1548,{ }^{13}$ uden at en ny abbed blev valgt, men derefter synes klostrets prior at være indtrådt $i$ en lederrolle. I hvert fald ser man i 1552, at prioren optræder "på klostrets vegne.$^{14}$ Samme år forlod prioren klostret og blev sognepræst $i$ den nærliggende landsby Abild. Dermed var det under alle omstændigheder slut med gejstlig indflydelse på klosteradministrationen.

Over for denne synsmåde må man fremhæve kilder, som sandsynliggør, at hertug Hans meget hurtigt har fået et ret fast greb om klostret. Vi ved, at hertugen personligt var i Løgumkloster ved flere lejligheder i årene 1545-46, ${ }^{15}$ og at han allerede fra 1545 solgte ud af klostergodset. ${ }^{16} \mathrm{I} 1546$ var abbeden nødt til at sende bud til hertugen for at forklare om en drabssag, ${ }^{17} \mathrm{og} \mathrm{da}$ hertugen afgjorde sagen med at give frit lejde til drabsmanden, indskærpede han samtidig abbeden, at denne skulle respektere afgørelsen. ${ }^{18}$ Ligeledes ser man i 1546, at hertugen udsteder en benådning ${ }^{19}$ og bekræfter et fæstebrev, ${ }^{20}$ begge dele inden for klostrets jurisdiktion. Det har hidtil været upåagtet af forskningen, at nævnte fæstebrevsbekræftelse fra 1546 også omtaler, at fæsterens rettigheder skal sikres af »den nuværende og de kommende amtmænd i Lille Tønder og befalingsmænd over Lumcloster «. ${ }^{20}$

Alt dette tyder på, at hertugen hurtigt har sat sig fast i Løgumkloster med amtmanden $\mathrm{i}$ Tønder som den overordnede administrative leder og med en »befalingsmand « $i$ spidsen for en lokal verdslig administration, hvortil måske også hørte den "gårdfoged «, som er nævnt $1546 .{ }^{21}$ En regulær hertugelig foged, Svend Dynes, er næunt i $1549,{ }^{22}$ og fra samme år aflægger klostrets skriver regnskab for hertugen. ${ }^{23}$

Den forvaltningsmæssige konstruktion med en lokaladministration af klostergodset underlagt amtmanden i Tønder ses gentaget i 1552, hvor Hans Michelsen nævnes som amtsskriver i Løgumkloster, ${ }^{24}$ mens amtmanden i Tønder betegnes som klostrets »bestyrer« eller »forstander $\ll .{ }^{14}$ Denne forvalt- 


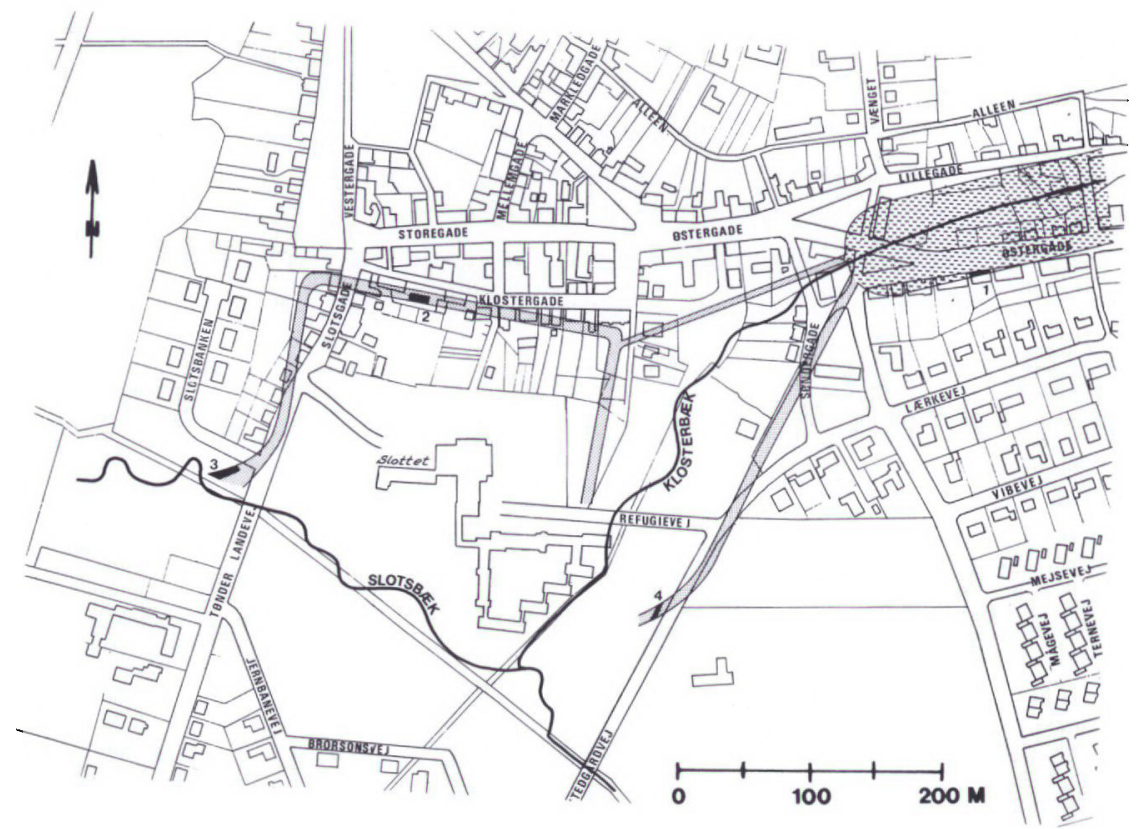

Slottets storhed har forst og fremmest vist sig gennem arkaologiske undersogelser 1976-86, der har afsloret et vidtlaftigt voldgravssystem (her indtegnet pd et moderne bykort; storre undersogelser angivet med tal). NTS del. 1987.

ning fortsatte sandsynligvis de følgende år. I hvert fald var klostret som institution repræsenteret af amtmanden $\mathrm{i}$ Tønder på hertugdømmernes landdag i $1564 .{ }^{25}$ Amtmand i Tonder var fra 1546 til 1560 Christoffer Rantzau, derefter Benedict Ahlefeldt indtil 1578 eller 1579.

I 1566 blev nedskrevet et "Inventarium for Klostret Løgum Kloster «. ${ }^{26} \mathrm{Her}$ er anført en række rum, som afspejler den verdslige ejer og den verdslige administration: fyrstens kammer, amtmandens kammer, skriverens kammer, junkernes kammer og kancelliet. Da inventariet omhandler klostret Løgum Kloster, kan man være sikker på, at amtet endnu ikke var oprettet. Derudover må man regne med, at hertugen og amtmanden (over Tønder amt) med deres følge har kunnet indrette sig under midlertidige ophold $i$ dele af den bygningsmasse, som stod ledig fra klostertiden. Der kan dog ikke klart peges på, hvilke rum der benyttedes.

Om den post som »befalingsmand over Løgumkloster", der omtaltes i kilden fra 1546, blev opretholdt, ved vi ikke. Men i 1567 dukker den op igen, idet Diderich von Landsberg nævnes som »høvedsmand « i Løgumkloster. ${ }^{27}$ I 1568 nævnes samme person som amtmand i Løgumkloster. ${ }^{28}$ Her træder endelig 
det selvstændige amt klart frem, idet Diderich von Landsberg hverken før eller senere nævnes i forbindelse med noget andet amt. Han nævnes forøvrigt igen i 1578 som "Hauptmann« i Løgumkloster, ${ }^{27}$ sådan at det kan være usikkert, hvorvidt han har været amtmand $i$ hele perioden fra 1568 , indtil han igen i 1584 nævnes som amtmand i Løgumkloster. ${ }^{27}$

Men da havde amtet allerede skiftet ejer. Efter hertug Hans' død i 1580 overgik amtet til hertugerne af Gottorp i følgende række:

$$
\begin{aligned}
& \text { 1581-86 Adolf, } \\
& \text { 1586-87 Frederik II, } \\
& \text { 1587-90 Philipp, } \\
& \text { 1590-1616 Johann Adolf. }
\end{aligned}
$$

I denne periode nævnes følgende amtmænd i Løgumkloster uden tilknytning til andre amter:

1584 Diderich von Landsberg, ${ }^{27}$

1586(1584?), 1588 og 1590 Henneke von Hagen, ${ }^{29}$

1593-98 Sievert von der Wisch ${ }^{30}$

Derefter følger amtmænd, som havde både Tønder og Løgumkloster amter under sig:

$$
\begin{aligned}
& \text { 1599-1608 Dietrich Blomen, }{ }^{31} \\
& \text { 1608-1616 Hans von der Wisch. }{ }^{32}
\end{aligned}
$$

Det kan altså slås fast, at der i perioden 1568-98 ikke er forhold, som tyder på en tilknytning for Logumkloster amt til andre amter. Det publicerede kildemateriale tillader derfor den slutning, at Løgumkloster amt $\mathrm{i}$ denne periode var et selvstændigt amt med egen amtmand. Inden for denne periode kan man se en begrundelse for nybyggeri i Løgumkloster, idet der må have været behov for en tidssvarende og passende repræsentativ residens for amtmanden. Desuden må der til enhver tid have eksisteret passende faciliteter til brug ved hertugens midlertidige ophold.

\section{Hertug Hans' hus og hertug Adolfs slot}

De første hertuger i tidsrummet 1568-98 var Hans den Fldre og Adolf. Begge var initiativrige, handlekraftige og byggeglade regenter, og de er begge mulige bygherrer i Løgumkloster. Hertug Hans var imidlertid ugift og langt mere nøjsom i sin hofhusholdning end hertug Adolf. Derfor er det næppe så sandsynligt, at det store slotsanlæg skyldes hertug Hans. Et storstilet slotsan- 
læg ville derimod passe glimrende til indtrykket af den pragtelskende hertug Adolf, som tillige var gift.

De tre Adolf-sønner, der efterfulgte ham som hertug af Gottorp og dermed som ejer af Løgumkloster, har ikke markeret sig som bygherrer i synderlig grad. Derfor kan nybyggerier af stort format bedst tænkes udført i tidsrummet 1568-86.

Fortæller kilderne da slet ikke om byggeri i Løgumkloster? Faktisk ikke direkte! Men indirekte taler både en arkæologisk kilde og en skriftlig kilde.

Ved arkæologiske undersøgelser under den nordvestlige del af den bevarede slotsbygning er fundet ydermurene af et klart markeret hjørne af en solid teglstensbygning, som er blevet opført efter nedrivning af middelalderlige klosterbygninger på stedet, men for opførelsen af slotsbygningen.

Endvidere foreligger et inventarium fra $1587,{ }^{26}$ hvori opregnes rum til fyrstepar, amtmand og hoffolk $i$ et sådant antal, at nybyggeri i større stil næsten giver sig selv. $\mathrm{Nu}$ findes fyrstens kammer, hertugindens kammer, junkernes kammer, amtmandens sovekammer, amtmandens forgemak, fruernes kammer, pigernes kammer, amtskriverens kammer, svendenes kammer. Inventariet opregner rummene, uden at det med sikkerhed kan fastslås, hvilke bygninger der var $\mathrm{i}$ brug på dette tidspunkt. Kun een bygning nævnes specielt: »det lange nye hus«! Det vil sige, at kort før nedskrivningen af inventariet er en ny bygning af betydelig længde blevet opført.

Den arkæologiske iagttagelse og den skriftlige kildes udsagn skal betragtes under hensyntagen til ejerskiftet efter hertug Hans' død 1580 (på grund af arveretmæssige forhold kunne hertug Adolf først tage Løgumkloster amt $\mathrm{i}$ besiddelse 1581) - og til de forskelle i personlig karakter og behov, som adskilte de to ejere. Herved kan man nå til en plausibel forklaring på både bygningshjørnet under slottet og »det lange nye hus«.

Kort tid efter oprettelsen af det selvstandige amt (ca. 1568) blev opført en solid bygning, hvoraf vi foreløbig kun kender et hjørne. Bygningen tjente hertug Hans' tid ud som amtmandsresidens, og her kunne hertugen indlogeres under besøg.

Dette byggeri tilfredsstillede øjensynligt ikke hertug Adolf, som lagde stor vægt på repræsentative slotsanlæg. Således lod han i årene 1573-82 hele tre slotte opføre fra grunden: Reinbek, Husum og Tønning. Det er derfor endog særdeles sandsynligt, at han efter overtagelsen af Løgumkloster amt ønskede at manifestere sig som en magtfuld regent $i$ et nyerhvervet landområde gennem et stort slotsanlæg, der synligt for enhver kundgjorde den nye hertugs tilstedeværelse.

Hertug Hans' bygning har sikkert ikke været imposant nok for hertug Adolfs smag, eller den har ligget ubekvemt for det større anlæg, som hertug 
Adolf ønskede. Hertug Hans' bygning blev derfor nedrevet, og hen over tomten blev bygget »det lange nye hus«, der højst sandsynligt er identisk med slottets endnu eksisterende hovedfløj. Denne bygning har stået færdig kort før 1587. Muligvis har hertug Adolf ikke selv oplevet bygningens færdiggørelse, idet han døde allerede 1586. Og det kan vel tænkes, at slotsanlægget $\mathrm{i}$ sin

Hertug Adolf af Gottorp, Logumkloster slots formentlige bygherre. Maleri fra ca. 1580 pd Eutin slot. Historiske Samlinger. Aabenraa.

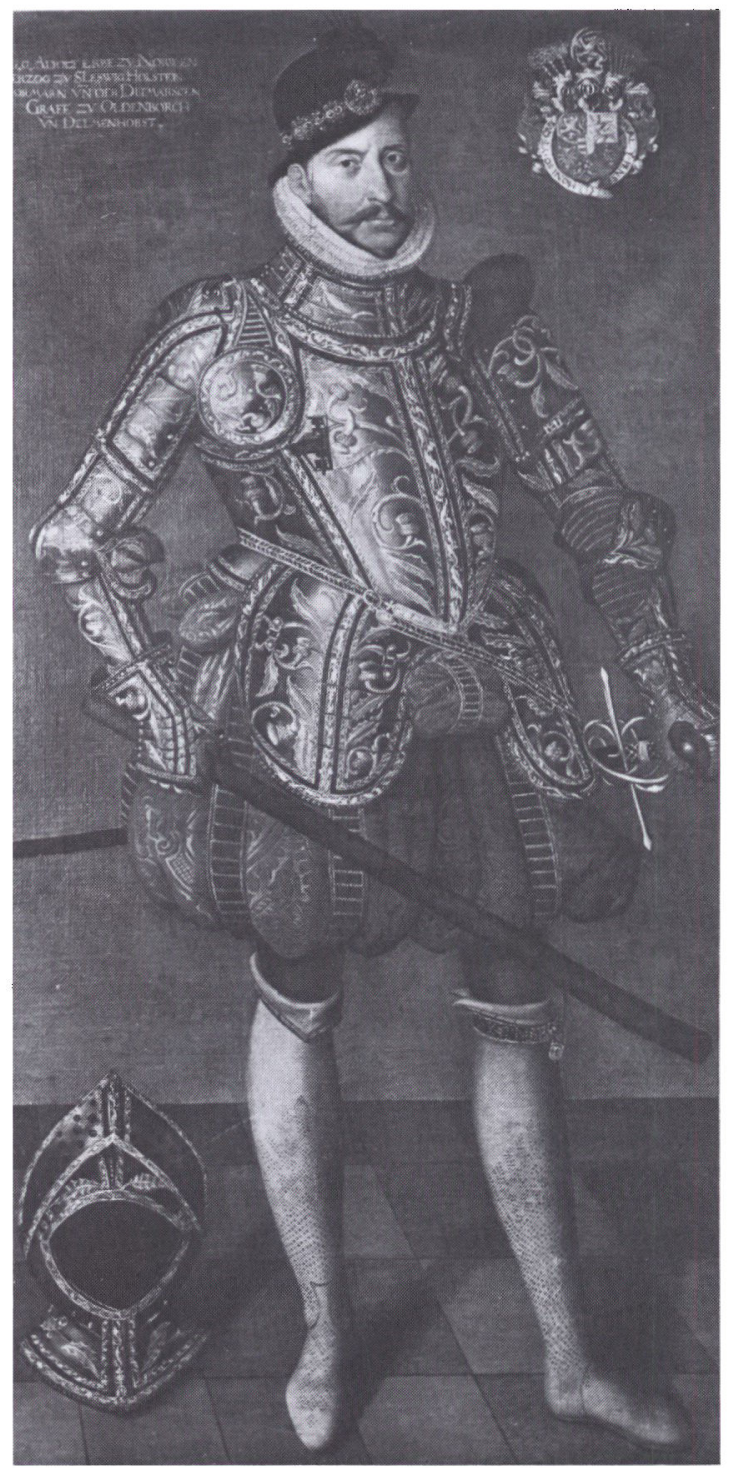


helhed ikke var fuldført førend nogen tid efter hertugens død. Men at planerne for anlægget blev udformet i hertug Adolfs tid, derom kan der ikke være tvivl. Ingen af Løgumklosters tidlige verdslige ejere havde bygherreambitioner i blot tilnærmelsesvis samme grad som hertug Adolf.

Interessen for Løgumkloster som hertugeligt slot var sandsynligvis borte allerede med hertug Adolf, og hans efterfølgere lod det øjensynligt hurtigt synke ned i glemsel. Allerede fra 1599 var slottet ikke længere amtmandsresidens. Dette bortfald af motiv for byggeri i større stil indicerer kraftigt, at slottet må være opført klart før det postulerede årstal 1614.

Om Logumkloster amt i det tidlige 1600-tal ved vi, at en rest af amtsforvaltningen med en amtsskriver ${ }^{33}$ i spidsen forblev i den eksisterende bygningsramme. Det er helt usandsynligt, at slottet skulle være bygget for at huse dette beskedne embede.

Efterforskninger omkring Løgumkloster amt fører således til yderligere afvisning af årstallet 1614 som slottets byggeår og til 1568-98 som en sandsynlig byggeperiode. Overvejelser angående amtets ejere i dette tidsrum fører til, at slottet mest sandsynligt er planlagt og (måske kun delvis) opført under hertug Adolf 1581-86.

De efterfølgende ejere lod slottet forfalde. Nedrivninger foregik under de gottorpske hertuger, under de danske konger og under den preussiske regering helt frem til 1878, hvorefter mindre end halvdelen af den centrale slotsfirkant stod tilbage. Denne rest er i 1900-tallet blevet gennemgribende restaureret og står i dag som et fornemt monument, der i lige grad repræsenterer middelalderens velkendte cistercienserkloster og renæssancefyrstens upåagtede slot.

\section{LITTERATUR}

Andersen, E. (1949): De hansborgske Registranter, Bd. II, Breve i uddrag 1543-1549. København. Andresen, L. (1939): Geschichte der Stadt Tondern bis zum dreissigjährigen Krieg (1627). Schriften zur Volksforschung Schleswig-Holsteins. Bd. 1. Flensburg.

Andresen, L. og Stephan, W. (1928): Beiträge zur Geschichte des Gottorfer Hof- und Statsverwaltung von 1544-1659, Bd. 2. (Quellen und Forschungen zur Geschichte Schleswig-Holsteins, Bd. 15) Kiel.

Diplomata ad monasterium Locum Dei pertinentia, ab anno 1173 ad annum 1578. Scriptores Rerum Danicarum (Jacobus Langebek ed.), Tom VIII, Copenhagen 1834, pp. 1-258.

Falkenstjerne, F. og Hude, A. (1895-99): Sønderjydske Skatte- og Jordebøger fra Reformationstiden. København.

Haase, N. (1977): Die wirtschaftlichen und sozialen Verhältnisse in Lügumkloster im 18. Jahrhundert. Schriften der Heimatkundlichen Arbeitsgemeinschaft für Nordschleswig, Heft 34-35, Jahrgang 1976-77, pp. 4-209. Apenrade (Aabenraa).

Haupt, R. (1888): Die Bau- und Kunstdenkmäler in der Provinz Schleswig-Holstein. Bd. 2. Kiel. Ipsen, A. (1852): Die alten Landtage des Herzogthümer Schleswig-Holstein von 1588-1675. Kiel. Kroman, E. (1959): De sønderjyske fyrstearkiver. Vejledende arkivregistraturer X. København. 
Mackeprang, M. (1929): Artikel "Tinghuset« i J.P. Trap, De sønderjydske Landsdele. Særtryk af Kongeriget Danmark, 4. udg., p. 266. København.

Mackeprang, M. (1932): Vaabentavlerne paa Slottet i Løgumkloster. Sønderjydsk Maanedsskrift 1932, pp. 145-147.

Mackeprang, M. (1945): Løgum Kloster og dets Gods. Sønderjydske Aarbøger 1945, pp. 20-127.

Smith, J. (1954): Slesvigske Amtsforvaltere. Studier og Personalhistorie vdr. Oppebørselsvæsenet i Hertugdømmet Slesvig indtil 1864. København.

Stemann, C. L. E. (1866): Geschichte des öffentlichen und Privatrechts des Herzogthums Schleswig. II. Teil. København.

Sterum, N. T. (1987): Se, det var et rigtigt slot. Danmarks langste udgravning - arkæologi pá naturgassens vej (red. Rigsantikvarens Arkæologiske Sekretariat), p. 401-406. Herning.

Wissing, J. A. (1980): Løgum Kloster i de første årtier efter reformationen. Overvejelser vedrørende Løgumkloster amts inventarlister fra 1566 og 1587. Legumkloster-Studier 2, pp. 101-128. ( Deut. Zusammenfass. Das Kloster Lögum in den ersten Jahren nach der Reformation. Betrachtungen über Inventarien des Amtes Lügumkloster in den Jahren 1566 und 1587, p. 129). Løgumkloster.

Wissing. J. A. (1984): Betragtninger vedrørende Slottet i Løgumkloster. Løgumkloster-Studier 4, pp. 117-142. (Deut. Zusammenfass. Betrachtungen über dass Schloss in Lügumkloster, p. 142f). Logumkloster.

\section{HENVISNINGER}

1. En undtagelse er Wissing 1984, p. 132, hvor det nævnes uden nærmere kilde, at amtet var selvstændigt med egen amtmand og formentlig med amtmandsresidens i Logumkloster i perioderne 1589-91 og 1593-98.

2. Sterum 1987.

3. Haupt 1888 , p. 591 , uden nærmere kilde.

4. Mackeprang 1932, p. 145.

5. Mackeprang 1929, p. 266.

6. Kun trykt materiale inddrages, idet forfatteren som arkæolog ikke er arkivkyndig. Lektor Henrik Fangel, Institut for sønderjysk lokalhistorie, Aabenraa, og Dr. Nicolai Haase, Flensborg, takkes for gennemlasning af manuskript.

7. Eksempelvis Kroman 1959, p. 62. Direkte vildledning findes omkring en kilde fra dette år; en skatteliste er publiceret med titlen "Frøkenskat i Løgumkloster Len 1548« (Falkenstjerne og Hude 1895-99, pp. 387-390), mens titlen $i$ anden sammenhæng anføres som »Regnskab over frøkenskatten i Løgumkloster amt 1548«(Kroman 1959, p. 83). Det originale arkivalie indeholder hverken betegnelsen amt eller betegnelsen len (venligst meddelt af arkivar Anne Thestrup, Rigsarkivet), og det giver således ingen konkret oplysning om administrationen af klostergodset.

8. Andresen 1939, p. 29.

9. Andresen 1939, p. 30.

10. Diplomata, p. 116, jfr. Mackeprang 1945, p. 37.

11. Diplomata, p. 60, jfr. Mackeprang 1945, p. 37.

12. Diplomata, p. 65, jfr. Mackeprang 1945, p. 40.

13. Hansborg-arkivet XXXIX, 29c, jfr. Mackeprang 1945, p. 111.

14. Hansborg-arkivet XXXIX, 29c, jfr. Mackeprang 1945, p. $111 f$.

15. 5 breve underskrevet af hertug Hans i Løgumkloster, jfr. Andersen 1949, pp. 233 fog $336 \mathrm{f}$.

16. Hansborg-registrant 1544-60, 3b, jfr. Andersen 1949, p. 225.

17. Hansborg-arkivet XXXIX, 29f, jfr. Andersen 1949, p. 316, note 1.

18. Hansborg-arkivet XXXIX, 31, jfr. Andersen 1949, p. 316.

19. Hansborg-registrant 1544-60, 45b, jfr. Andersen 1949, p. 336.

20. Hansborg-registrant 1544-60, 31, jfr. Andersen 1949, p. 337.

21. Diplomata, p. 151, jfr. Mackeprang 1945, p. 37. 
22. Stemann 1866, p. 141; ingen oplysning om originaldokument. Foged Svend Dynes er nævnt adskillige gange 1549-50 i Diplomata.

23. Mackeprang 1945, p. 112; ingen oplysning om originaldokument.

24. Hansborg-registrant 3, fol. 221, jfr. Smith 1954, p. 102. Hans Michelsen nævnes også 1567 og 1568, Diplomata p. 21 resp. 19.

25. Hyldningsdokument jfr. Ipsen 1852, p. 12, anmærkning. Amtmanden i Tønder 1564 var ikke Dietrich von Landsberg som anført hos Haase 1977, p. 123, og hos Wissing 1980, p. 102, men Benedict Ahlefeldt (jfr. Andresen og Stephan 1928, bd. 2, p. 379).

26. Wissing 1980, gengivelse in extenso.

27. Stemann 1866, p. 141; ingen oplysning om originaldokument. Von Landsberg er nævnt $i$ brev af 25.8.1567, Diplomata p. 74 (venligst meddelt af Henrik Fangel).

28. Hansborg-registrant XIII, bl. 202, 265, 285, jfr. Andresen 1939, p. 41. Haase 1977, p. 123, benævner Dietrich von Landsberg som klostrets forstander ("Verweser«) i modsætning til Andresen anf. st., der klart bruger betegnelsen "amtmand«. Også Mackeprang 1945, p. 112, bruger betegnelsen amtmand ud fra samme kilde.

29. Andresen og Stephan 1928, bd. 2, p. 8, note 14.

30. Andresen og Stephan 1928, bd. 2, p. 18, note $36 \mathrm{~g}$ og p. 370 .

31. Andresen og Stephan 1928, bd. 2, p. 8, note 13.

32. Andresen og Stephan 1928, bd. 2, p. 379.

33. Smith 1954, p. 102f. 